This item was submitted to Loughborough's Research Repository by the author.

Items in Figshare are protected by copyright, with all rights reserved, unless otherwise indicated.

\title{
Who reads the project file? Exploring the power effects of knowledge tools in construction project management
}

PLEASE CITE THE PUBLISHED VERSION

http://dx.doi.org/10.1080/01446191003725154

\section{PUBLISHER}

(C) Taylor \& Francis (Routledge)

\section{VERSION}

AM (Accepted Manuscript)

\section{LICENCE}

CC BY-NC-ND 4.0

\section{REPOSITORY RECORD}

Sage, Daniel J., Andrew R.J. Dainty, and Naomi Brookes. 2019. "Who Reads the Project File? Exploring the Power Effects of Knowledge Tools in Construction Project Management". figshare.

https://hdl.handle.net/2134/11114. 
This item was submitted to Loughborough's Institutional Repository (https://dspace.lboro.ac.uk/) by the author and is made available under the following Creative Commons Licence conditions.

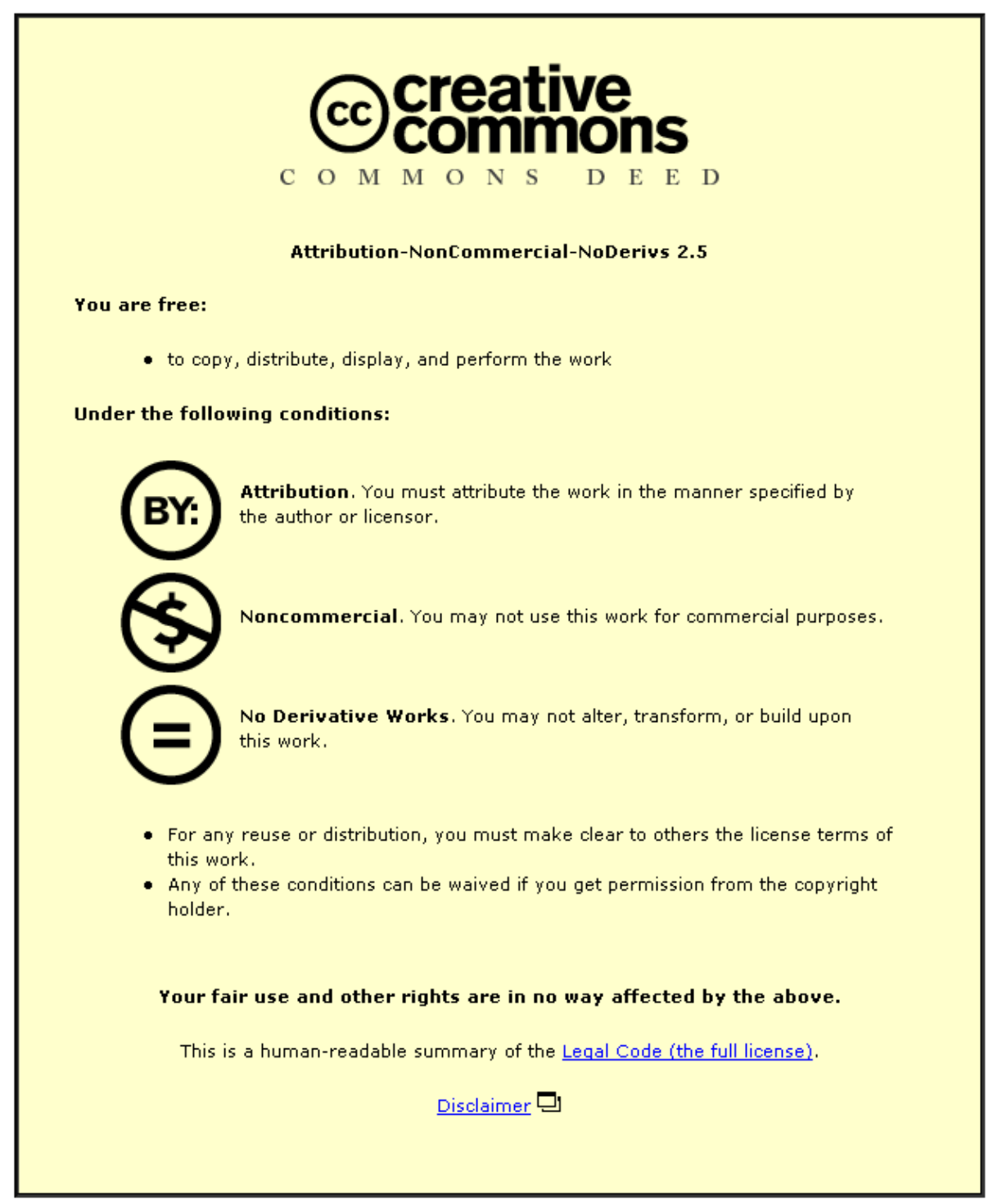

For the full text of this licence, please go to: http://creativecommons.org/licenses/by-nc-nd/2.5/ 
Who Reads the Project File?: Exploring The Power Effects of Knowledge Tools in Construction Project Management (paper submitted for the Special Issue on Objects, Knowledge Sharing and Knowledge Transformation in Projects, edited by Mike Bresnen and Chris Harty)

\author{
Daniel Sage \\ Department of Civil and Building Engineering, \\ Loughborough, Leicestershire \\ LE11 3TU \\ Andrew Dainty \\ Department of Civil and Building Engineering, \\ Loughborough, Leicestershire \\ LE11 3TU \\ Naomi Brookes \\ Department of Civil and Building Engineering, \\ Loughborough, Leicestershire
}

LE11 3TU 


\section{Abstract}

Various critical authors have questioned the salience, efficacy and power effects of formal project management bodies of knowledge (PMBoKs). As a result project management knowledge tools are increasingly being conceptualized along more flexible, adaptable, reflexive, democratic and informal terms. A central driver for this shift is that PM knowledge will be more relevant and useful for practitioners if it can be reflexively tailored to fit local project scenarios, emergent problems and different communities of practice, rather than projects being structured to fit generic "best practice” ideals. Hence new knowledge tools increasingly would appear critical to alleviate various detrimental power effects associated with bureaucratic knowledge practices within project-based industries, not least construction. This assumption is examined through a study of a formal and codified project management knowledge tool - a project file - within a small team of project practitioners in a large civil engineering consultancy. Various concepts of power related to Actor Network Theory (ANT) are mobilised to understand how nonhuman artefacts can enact power and knowledge in nuanced ways within organizations. This theoretically informed study will aid both researchers and practitioners interested in the consequences of developing prescriptive or reflexive project management knowledge within construction contexts and beyond.

Keywords: knowledge, power, project management, Actor Network Theory,

\section{Introduction}


Project management (PM) is widely recognized as the core discipline of construction management knowledge (Walker, 2007; Winch, 2002). Construction management scholars, practitioners and government have advocated a plethora of seemingly highly standardized, structured and prescriptive formal PM knowledge tools, techniques, frameworks and models to develop organizational value. Assumptions regarding the value of sharing standardized and structured PM knowledge, and knowledge management processes, to improve project performance can be found inter alia, in Lean Construction (Egan, 1998), various Key Performance Indicators (Yeung et al, 2007), Critical Success Factors (Kulatunga et al, 2009) as well as external standards such as ISO9001 or PRINCE2. By contrast, critical project studies (Hodgson and Cicmil, 2006a; 2007; 2008; Cicmil et al, 2009a), and other interpretative studies of PM (Crawford et al. 2006; Crawford and Pollack, 2007; Morris et al. 2006) have questioned the efficacy, relevance and consequences of standardizing PM knowledge and practices, instead they encourage a more reflexive, or transformative, view of PM knowledge production and circulation.

Drawing upon interpretative and critical approaches to knowledge in management studies (e.g. Fournier and Grey, 2000; Stacey, 2001; Styhre, 2003; Weick, 1995), a variety of more reflexive, transformative, democratic, collaborative and informal tools, techniques and guidelines have been proposed to develop PM knowledge (e.g. Bellini and Canonico, 2008; Cicmil, 2006; Cicmil et al. 2009b; Crawford et al, 2006; Smith, 2007). PM knowledge tools and techniques frequently claim to represent projects and project management: functioning as passive artefacts that claim to represent an object “out there”. By contrast, critical approaches consider how such 
tools help coordinate a network of relations constructing "the project" and "project management” - serving and legitimizing specific interests and ideologies and silencing others, constitutive of and through relations of power (Hodgson and Cicmil, 2006b). These approaches have examined PM knowledge artefacts such as Gantt charts (Yakura, 2002) and PMBoKs (Hodgson and Cicmil, 2006b). Hodgson and Cicmil (2006b), for example, suggest how the PMI’s PMBoK reifies PM knowledge, "as definitions, techniques and procures become set in stone..removing the ethical and political questions from the agenda", hence "the establishment of universal knowledge of this kind implies a loss of a reflexive and embodied rationality in favour of abstract principles and blind faith in universal techniques” (p48). Or more worryingly, "standardized PM often is itself the cause of project overload, cultural clashes, and engenders individual resistance to imposed procedures and practices” (Hodgson and Cicmil, 2008: 144). These comments exemplify a pejorative proposition, shared by most critical and interpretative project approaches: structured and prescriptive universal PM standards are frequently ineffective in successfully delivering projects (Cicmil, 2006; Cicmil et al. 2006; Cicmil et al. 2009b; Crawford et al. 2006). Some critical approaches have gone further and shown how such knowledges are ethically and politically pernicious increasing oppression and exploitation within organizations, and by extension society (see Cicmil et al. 2009a; Hodgson and Cicmil, 2006a). The overarching aim of this paper is therefore to undertake an empirical exploration of the consequences of adopting more reflexive approaches to PM knowledge sharing and transformation than the seemingly topdown, highly standardized and structured view of knowledge offered within various PMBoKs. In doing so we examine a seemingly standardized project knowledge artefact, the 'Project File'. By using an ANT lens to understand the project file's 
utility and potency within a construction project environment we hope to reflect on the ambiguities of standardization and reflexivity, powerfulness and impotence that it accretes. We also seek to make a cogent argument for the wider use of an ANT lens in understanding other project knowledge artefacts.

In the case of construction it is debateable how much overly standardized and structured project management actually impacts upon the highly fragmented and chaotic work process, particularly on site (Green, 2006). However, a great deal of construction activity, particularly design, takes place off-site in stable office environments. PM knowledge within this context is perhaps more amenable to constructing Weberian iron cages (Weber, 1958) or Foucauldian prisons (Foucault, 1977). We might therefore infer that design defects and buildability issues which are often associated with project failures (Jha and Iyer, 2007), might be indicative of the imposition of un-reflexive and de-contextualized formal PM knowledge tools, artefacts and objects that reify abstract standards (Hodgson and Cicmil, 2006b). And yet, it is notable that despite the ever growing range of empirical studies examining the imposition and consequences of standardized PM knowledge across particular projects, organizations or industries (see Cicmil et al. 2009a; Crawford and Pollack, 2007; Hodgson and Cicmil, 2006a), very few studies have examined in detail how a single PM artefact, standardized or flexible (or perhaps both), actually contributes to power effects in a specific organizational setting. This question is important because, as Latour (2005: 86) suggests, if we do not understand precisely the various unlikely and small socio-material mechanisms and conduits through with relations of power operate then we cannot understand and modify them. In the next section we will follow Latour's relational logic across a conceptual terrain called Actor-Network 
Theory (ANT) that contains various concepts to examine the minutia of associations of power, knowledge and materiality. ANT provides a powerful lens for understanding the role of PM objects in shaping power effects within project-based organizations.

\section{Actor-Network Theory: Power, Knowledge and Materiality}

ANT studies have developed a number of concepts to consider the stabilizing and transformative role that inanimate objects, or "nonhumans" (Latour, 2005), play in enacting knowledge and power - potentially liberating or oppressing individuals, not least within organizations (Czarniawka and Hernes, 2005; Law, 1994; Law and Singleton, 2005; Whittle and Mueler, 2008). ANT suggests that knowledge and power (and space, time and scale) is the successful outcome of a complex network of alignments between actors (humans and nonhumans) that requires a great deal of effort to be maintained (Callon, 1986; Latour, 1987). These networks do not represent reality in the customary sense at all where knowledge passively describes an objective reality out there - they have nothing to do with depictions of the networked society or social networks (Latour, 2005: 129-130) - rather they produce realities out there such as "the economy", "nature” or "society” through relational processes of translation (Latour, 2005). Knowledge and power are produced across network translations where one site is, somewhat paradoxically, faithfully transported into another through “massive transformations” (Latour, 2005: 223). Translation implies transformation because, as Law (2007) explains, “To translate is 
to make two words equivalent. But since no two words are equivalent, translation also implies betrayal: 'transduction, trahison [treason]'. So translation is both about making equivalent and about shifting” (p4). These networks of translation produce powerful "macro-actors" (Callon and Latour, 1981): actors that function as "spokespersons" constructed around "obligatory passage points" and "interessement devices”, through which they can influence and speak for other actors (Callon, 1986; Latour, 1987).

ANT shares some similarities with Foucauldian studies of power and projects (Cicmil et al. 2006; Marshall, 2006) and construction (Bresnen et al, 2005; Harty, 2005); where power is not owned, and is not separate to knowledge, but is rather an effect of knowledge dependent upon the production of consenting individuals through materially constituted discourses (Foucault, 1977). Both Foucauldian and ANT studies affirm that power effects, whether the outcome of discourses or actornetworks, can be both productive and negative, simultaneously constraining and enabling action. ANT scholars have, however, criticized Foucault (Law, 1991; 1994, 2002) and his followers (Latour, 2005: 86) for focussing upon macro discourses and invisible power relations that sometimes seem to obscure rather than elucidate the more quotidian ways in which "power-knowledge-discourse" mutates, bifurcates, interacts and transforms. Law (2007) proposes that "actor networks can be seen as scaled-down versions of Michel Foucault's discourses” (p5). ANT describes the precise empirical associations through which human or nonhuman actors are able to concurrently draw power to and over others (Law, 1991), it remains open to the possibility that this translation could fail at anytime, may be subject to anti-programs (Akrich and Latour, 1992), is only as strong as its weakest link (Latour 1987: 121), 
and may require new techniques, tricks and strategies of association to maintain a network and its power effects (Callon, 1986).

ANT studies have broadened beyond the single-network version popularized by Callon (1986); these studies have documented different power effects. Objects may, for instance, help mediate multiple actor-networks, offering interpretative flexibility as cosmopolitan "boundary objects" - co-ordinating, and preserving, different knowledge practices (Star and Griesmar, 1989). Nonhumans can enact fluidity, resisting enrolment by "macro actors", enabling and empowering emergent knowledge practices outside of formal actor-networks (de Laet and Mol, 2000; Mol and Law, 1994). Actors may also be functionally blank, appearing almost absent in the actor-network, yet providing unpredictable power/knowledge effects by virtue of their indefinite capabilities for association (Hetherington, 2000). Materialities, including human bodies (Mol, 2002), may be multiple whilst appearing to act as one; creating powerful consequences for our capacities to know and alter their divergent agencies (Law, 2002; Law and Singleton, 2005). These different versions of ANT have been developed to respond to accusations that the single-network version of ANT (e.g. Callon, 1986) promotes a rather totalitarian (Lee and Brown, 1994; Munro, 1999; Whittle and Spicer, 2008) or masculinist (Haraway, 1997; Star, 1991) view of knowledge/power - where everything becomes susceptible to translation by totalizing actor-networks, leaving limited potentiality for human agency and difference. It is important to bear these different ANT approaches in mind when accounting for the nuanced power effects of nonhumans. 
ANT accounts of socio-materialities help to avoid technological or social determinism (Latour, 2005: 84), however it must however be recognized from the outset that the motivation for starting with formal and codified PM tools does not purely emanate from ANT. The rationale for focussing upon formal and codified PM knowledge tools is the increasingly prevalent proposition, exemplified by critical and interpretative PM approaches, that more flexible, and contextually responsive, PM knowledge provides an antidote to some of the pernicious power effects of universal PM standards. ANT concepts have already been used to describe the unpredictabilities associated with reorganization projects (Molloy and Whittington, 2006), the implementation of standardized PM knowledge systems (Linde and Linderoth, 2006) or the emergence of project roles (Georg and Tryggestad, 2009). However no ANT studies have, thus far, sought to explicitly examine the power effects of specific PM knowledge tools. Likewise, although ANT has been used to examine the socio-material complexity of building design (Ewenstein and Whyte, 2009; Harty, 2005), these studies have not explicitly addressed the power effects of PM tools in the design process.

Of course, we must acknowledge in addressing this topic that critical project studies have recognized that PMBoKs are often necessarily flexible in application (Hodgson and Cicmil, 2006: 47; Hodgson and Cicmil, 2007: 446), and their power effects are always contextually mediated provoking points of resistance and transformation rather than enacting omnipresent and omnipotent domination (Marshall, 2006). Moreover there is always a danger, as Hodgson and Cicmil (2007: 447) recognize, that local workarounds to imposed standards may paradoxically allow a standard to continue in some form, perhaps leaving some power effects intact. Such paradoxes, 
and nuances, regarding the power effects of highly standardized, structured and prescriptive PM knowledge tools are central considerations for this study. Despite such caveats there is still a value judgement underpinning most critical and interpretative PM research, that more flexible, contextually appropriate, and reflexive, PM knowledge is better able to mitigate or modify some of the pernicious power effects of standardized, structured and prescriptive PM knowledge (Cicmil, 2006; Cicmil et al. 2009b; Crawford et al, 2006; Smith, 2007). In the next section we will introduce the ANT-inspired methodology and the case study context within which we will examine this assumption.

\section{Methodology and Case Study}

ANT studies have deployed various methodologies to address socio-material complexities, including archival studies (Law, 1986), ethnographies (Law, 1994), textual analysis (Armstrong, 2005) and philosophical expositions (Hetherington, 2000). Whilst, Latour's (1987) insistence of “following the actors” seems to dictate an ethnomethodology of practice where all associations and actors must be taken into account, such an approach hardly captures the breadth of ANT studies (Law, 2007). In this context it also does not always seem possible to follow the actors because, as will be shown, the formal PM knowledge tool we encounter seems to be far less mobile or connected than those commonly described within ANT accounts. Indeed it often seems this object comes to a halt, is forgotten or ignored, placed outside a network, rather than regarded as pivotal to any grandiose project of network building (as in Callon, 1986). Hence, it was simply not feasible to conduct a long duration 
ethnographic study of this PM tool, not least because it remains dormant in the organization for extended periods of time.

We begin our narrative in a single setting in the UK: a small team of project practitioners within a particular office of large civil engineering consultancy (CivCo). Whilst this setting is not intended to be representative of the organization or the industry, it can be used to critically examine assumptions regarding the utility and consequences of PM knowledge tools. CivCo employs over 10,000 people in the UK and beyond, working in areas as diverse as highways, utilities, property management and management consultancy; it has a turnover of approximately $£ 1 b$. The projects undertaken by the studied team were small-scale road and pedestrian projects for local authorities, generally of less than $£ 5 \mathrm{~m}$ in value. This work is either undertaken directly for public sector clients, or more usually for an internal client that functions as an intermediary between the technical design work and the client. Initially, the entire team of twenty-one practitioners completed a questionnaire relating to PM in their organization. The results of these questionnaires, which are not examined here, were used to select a sub-group of individuals for follow-up semi-structured interviews on formal PM processes within the organization. The interviewees were chosen to reflect the range of responses (mean, high and low responses, and significant standard deviation within answers). Additionally, prior to the interviews we asked the organization to provide us with documentation related to formal PM processes; this particular organization provided us with a single PM file (known here as the "Project File" or simply "File”). In addition to these interviews we held more un-structured interviews with the manager of the team and the senior business process improvement manager (BPIM) within CivCo. 
The discussion is structured around four interrelated questions: Is the Project File a prescriptive standard? Is the Project File a reflexive tool? Is it something else? And what accompanying power effects does it create? In answering these questions we draw upon the voices of practitioners. We adopt a semi-autobiographical voice to help aid construction management researchers understand how ANT concepts can be deployed to examine how both standardized and reflexive PM tools mitigate or modify power effects, and hence the broader significance of PM artefacts as enactments of organization rather than passive “tools” (Hodgson and Cicmil, 2006b).

\section{The Project File as a Prescriptive and Structured Standard?}

The Project File consists of cardboard file dividers that structure the organization of knowledge around a project within CivCo. The front cover of the document describes the substantive dividers which organize knowledge across typical PM knowledge areas as contained in the PMI's PMBoK (e.g. planning, cost, communications and procurement) and other PM standards. The Project File focuses upon ensuring standardized knowledge and knowledge management processes for planning, monitoring and controlling the "iron triangle" preset of cost, time and quality objectives (Hodgson and Cicmil, 2006b). The Project File also emulates the PMI's reliance upon a linear Project Life Cycle (PLC) classically defined in command and control terms of conceptualization-planning-implementation-review (Cicmil et al, 2009b: 3). The individual file dividers and their accompanying procedures are ordered chronologically along the PLC. The PLC and the "iron triangle" have been argued help efface the possibility of emergent and non-linear project interactions, 
goals and outcomes, causing a problematic narrowing of the field of vision of practitioners and organizations (Cicmil et al., 2009b).

Each file dividers contains an introduction to the objective of each procedure, as well as a breakdown of specific tasks and relevant document codes of supporting forms and guidance notes available via the internal intranet system. The objectives are described in quite narrow, self-evident, terms. The "planning” divider notes that:

The objective of this procedure is to plan how the requirements of the client's brief will be met.

After introducing the objective each divider then lists various tasks that must be completed. These tasks are seemingly highly prescriptive, encouraging certain types of PM knowledge to be collected, often referred to standardized forms, presumably so that it can be easily shared, but perhaps above all this structured approach is seen as a good representation of the "real" nature of projects. This approach it is a good natural fit, perhaps in part because it mimics a body of extant PM knowledge (Hodgson and Cicmil, 2006b). The Control of Documents divider illustrates this structured approach in various tasks, for example:

The PM ensures that checks are in accordance with Category A, B or C checks as defined in the Project Plan.

Similarly on Planning: 
Internal project teams must sign the Confirmation of Familiarity record to show they understand and accept the Project Plan and their responsibilities within it.

The Project File is designed to be a "live" document rather than a structured report to be completed in one effort. This iterative function is supported by the availability of standardized forms on CivCo's intranet system, which can be inserted, alongside other forms of evidence, into the dividers as the project develops. The File refers to 24 standardized forms through which knowledge can be organized across the different knowledge areas. And yet in 9 cases the File indicates that equivalent forms can be used, for example:

The PM or nominee must prepare a Project Plan, or equivalent, to describe the work and decisions covered by all project work stages, including external vendors [emphasis added].

Through such equivocality it appears that some flexibility is enabled. However we should note that other classic PM notions such as the PLC, the emphasis on control, or objective knowledge areas (such as cost control, communication control), are still taken for granted. And moreover, the project file prescribes in subsequent task descriptions what an equivalent should contain and do; hence many practitioners might simply prefer to use the standardized form.

The information collected in this document refers to entities such as the "project", “project team”, “change control” or "project work stages” as unproblematically 
existing independent of our knowledge of them, hence the Project File appears to reproduce a realist, functionalist and objective view of PM knowledge (Hodgson and Cicmil, 2006b). The Project File, like the PMI's PMBoK, is also authored by a collective entity; this tactic is, as Hodgson and Cicmil (2007: 442) explain, often helpful in creating objective, rather than situated, knowledge. However unlike the PMI's PMBoK the Project File does not require a network of allies, such as corporations or other institutions to buttress its truth claims (Hodgson and Cicmil, 2007). The BPIM informed us that this document was created to fulfil the ISO9001 quality assurance (QA) standards in the organization yet no mention of this standard is given. It appears that the practitioners using this document do not require many “interessement devices” (Callon, 1986) to be persuaded of its validity and efficacy.

Viewed as a standalone text through ANT the project file might appear to be a blackboxed (Latour, 1987) macro-actor (Callon and Latour, 1981): a powerful networked actor through which "many elements are made to act as one” (Latour, 1987: 131). It appears the purpose and veracity of PM and "the project" is co-ordinated through the project file so that inputs (following defined processes) equal predictable outputs (successful projects). Hence the Project File might appear to be a powerful macroactor within the organization co-ordinating people and things, defining and enacting the success of CivCo. In this case we might easily assume that this object sustains a Weberian iron cage or Foucauldian prison - leaving practitioners with little room to manoeuvre, risking all the pernicious power effects of un-reflexive, de-politicized and de-contextualized PM knowledge (Hodgson and Cicmil, 2006b; 2007; Smith, 2007). A danger in casting this judgement now, however, is that no associations have been followed and so the object has been understood outside the social relations it 
may form. This type of technological determinism is antithetical to any ANT approach. Indeed, even if this object is a black boxed macro-actor it too requires a great deal of effort to be maintained, people to implement it, police its implementation and update and revise it, as and when required (Latour, 1987: 135-6). And moreover what associations might it form with other objects? We must not confuse a powerful explanation with an explanation of power (Latour, 2005: 85).

\section{Project File as Interpretative Tool}

Before we spoke to practitioners about the project file we might have easily believed that this object was very powerful indeed within CivCo - that it actively enforced all the pernicious power effects described by Hodgson and Cicmil (2006b). However the practitioners we spoke to described a rather different object. The procedures described in the Project File appeared far from self-evident, or "black boxed":

I have tried to understand parts of it myself and what they want. And then once I have completed what I think it is that needs to be done and someone comes along and says that ok fine but here you need to move this, you haven't said the right thing here, or this means such and such, and they will explain it properly then. And then you get more brought back onto the right track. (Design Engineer \#1)

This practitioner was new to CivCo and had not yet been self-disinclined by any possible interessement devices (the senior managers). We have already moved beyond technological determinism; the production of power and knowledge is 
heterogeneous as it composed of both social and non-social elements. The interpretative flexibility of the Project File requires a broad network of social allies (middle managers, regional managers, administrative assistants and other colleagues) to ensure compliance.

However it became increasingly apparent that interpretative flexibility was not merely an aberration, unique to new employees that the organization had yet to enrol in their actor-network. Indeed often such flexibility appeared actively encouraged by the senior managers. One senior engineer reported how the Project File enables transformations rather than mere alignment between global and local PM knowledge. He provided an example from the change control section of the project file. As already discussed, in several instances the Project File indicates that staff can opt not to complete standardized forms. This practitioner discussed the advantages of this flexibility for his team who undertake small-scale road design projects and have produced their own change control check-list in Microsoft Excel. This list provides substantially less detail on changes but makes the process less costly and timeconsuming, and so more appropriate for the type of projects the team undertook. In this instance the Project File does not seem to function as an all-encompassing corporate standard - becoming a powerful macro actor of imposed knowledge and managerial power. Whilst such transformation could be conceptualized as evidence that the File is a "leaky" black-box (Callon and Latour, 1981), or subject to subversive anti-programs (Alkrich and Latour, 1992), these concepts do not seem to account for the productivity of such transformations in knowledge sharing. Namely, the File appears to function as a boundary object (Star and Griesemar, 1989), mediating flexible PM knowledge between different actor-networks, or communities 
of practice (Wenger, 1998), rather than transforming one singular actor-network (as in Callon, 1986). Star and Griesemar (1989) explain how boundary objects (BOs):

..are objects which are both plastic enough to adapt to local needs and the constraints of the several parties employing them, yet robust enough to maintain a common identity across sites (p393).

Various authors have started to draw upon the concept of boundary objects to understand how knowledge can be shared between different communities of practice in project-based settings (e.g. Cacciatori, 2008; Koskinen and Makinen, 2009; Yakura, 2002). These studies illustrate how objects are significant in overcoming some of the communication problems imposed by the fragmentary and ephemeral character of project work. Of key practical importance here is the observation that standards can never fully prescribe the circumstances people encounter in diverse communities of practice, and so 'successful' knowledge standards must be able to accommodate this localized flexibility. Thus, there is a great deal in common between boundary objects studies and the reflexive PM techniques offered by the 'critical' and 'rethinking' PM movements, which emphasize reflexivity to local contexts (Cicmil et al. 2009b; Smith, 2007).

The Project File appears far from merely an imposed corporate standard, rather it is, to some extent, intentionally designed to be a locally flexible tool. We have already described how the Project File explicitly permits deviation from standardized forms in some instances, another example concerns role profiles. These profiles were designed to specify the kind of activities that different actors within a project would 
undertake, including project managers, quantity surveyors, design managers, project planners as well as the technical staff. The senior engineer explained how these attempts to specify roles were trialled in the Project File and then abandoned because they were far too specific for the differentiated projects undertaken across CivCo.

In addressing these diverse social interpretations it appears that this object empowers rather than oppresses practitioners. It seems a highly adaptable tool, helping practitioners to monitor and control their projects perhaps offering a knowledge toolbox of 'best practice' solutions (Morris, 2006) for reflexive practitioners helping to integrate different communities of practice. Indeed it is notable that the file was initially produced to help align the company after a recent merger. Hence we might suspect that this object is largely empowering rather than oppressing practitioners, enacting productive power. However, this perspective ignores the material associations it forms, perhaps avoiding technological determinism by defending social determinism (Latour, 2005: 84). The question now becomes does this interpretative flexibility modify and mitigate pernicious power effects within CivCo? Does it, indeed, enable CivCo to escape the problems of overly prescriptive knowledge - the Weberian iron cage of bureaucracy - and value more reflexive practice that can address unpredictability (Cicmil et al. 2006) and mitigate some of the pernicious social consequences of project work (Cicmil et al. 2009)?

\section{The Project File as Fractionally Coherent}

To answer this question we must follow the object itself, where does it travel what happens to it after it has been completed? We might imagine that the interpretative 
flexibility of the Project File is a vital aspect of its translational power. Perhaps the File operates as an 'immutable and combinable mobile' (Latour, 1987: 227): a highly mobile object that can reliably translate knowledge from one site into another through transformations - for example transforming change control forms into a database of projects - combining with others actors (computer systems, post trays, emails, managers, charts, reports, diagrams etc) to create a 'centre of calculation' (Latour, 1987: 233) from which strategic decisions can be made (Latour, 1987). However, unlike the classic ANT concept of an 'immutable mobile' (Law, 1986; Latour, 1987), this object does not seem to travel very far at all, it hardly seems to be an active mediator in the kind of dynamic actor-network outlined by Callon (1986).

For example, one junior engineer explained how “I honestly haven’t read it”. When asked what happens to the file he replied, "I think it is kept in the cabinet upstairs and anyone can access it but it's very rarely that I want to". A senior engineer provided a slightly less ambiguous answer when asked to explain what happens to the file:

I think the directors need to look at it, I think this is a check sheet basically and it says these people have been doing this.

However, when we spoke to the business process improvement manager (BPIM) in CivCo he informed us that the board of directors and most senior managers in the company did not know that the Project File existed. This Project File is hardly the focal point of panoptic organizational power (Foucault, 1977). The BPIM explained that the file had two purposes, first it had been developed to comply with ISO9001 
quality assurance standards, but above all it was designed to help practitioners. To acquire ISO9001 certification, CivCo had to undertake an external audit through which standardized processes were put in place to formalize and standardize PM procedures, which were seen as a vital aspect of quality management in CivCo. The CEO at the time had resisted this move to standardization as he felt that it would not be appropriate for the diversity of work undertaken, however he was persuaded to seek certification on the basis that all their competitors had gone down this path. CivCo was required, as part of ISO9001, to undertake internal audits every 6 months to ensure compliance with the standardized procedures. These audits were organized within this team by an administrative assistant who would ensure that all Project File produced over a period of time met a minimum requirement. She would then get approval of the audit from the senior manager in the team who would then report to the office manager. One junior engineer explained that the QA audit was really the main purpose of the Project File:

..it's the purpose of getting verified by quality assurance people, give us certificates to say we are working to this sort of standard, that's what it's all about at the end of the day..

The administrative assistant responsible for implementing the QA audit within this team of practitioners was cynical about the effectiveness of Project Files; she described how often they were not always completed contemporaneously and they were not necessarily used in everyday PM practice. Nevertheless this individual was keen to point out the importance of the QA audit and the Project File in maintaining the paper trail for possible liability claims if there was a problem with a project, 
namely if a project was late or over-budget. The retrospective role of the Project File appears key to the specific way it shapes power within the organization, namely as a technology of audit.

The significant impact of auditing on PM remains largely underexamined. Power (1997) characterizes modernity as the "audit society". Jary (2002) explains how the positive values of public accountability, openness and democracy has reciprocated "a search for new forms of institutional and individual 'reflexivity' ...central to the goal of greater control of a 'runaway world"” (p39). There is a clear parallel between the control culture of the audit society (Power, 1997) and that of project management. In both instances individuals are afforded some flexibility over the practices to achieve targets, yet they are subject to continuous self-disciplining, monitoring and control technologies. However unlike PM, the audit does not police performance directly rather it is more a "policing of policing" (Jary, 2002: 41), and hence is less visible. Jary (2002) suggests that highly prescriptive, structured, centralized and standardized audits (STYLE A) are problematic because the audit means become targets, often through data manipulation, so they do not really produce transparent or objective knowledge at all; they also intensify workloads causing stress, have a high cost and produce misleading statistics. Jary (2002) argues they should be replaced by more contextualized, localized, autonomous and trusting audits (STYLE B) that are capable of reflecting on the audit process themselves.

In CivCo the audit appears closer to STYLE B as outlined by Jary (2002: 42). Every 6 months project files were checked for QA compliance in a relatively standard way (ensuring forms were dated and signed), yet the audit was highly localized in the 
team, no external or long-distance audit methods were imposed. The fact that the Project File often failed to be contemporaneously maintained indicates that the Project File is hardly an objective measure of project performance, but rather is a 'best practice' approximation for this specific team. Once completed and checked the Project Files are all stored in the individual office. Most are forgotten by practitioners from senior directors to junior engineers; they are not used every day; many interviewees seemed surprised that we were discussing them at all. Because of their inactivity it is difficult to regard Project Files as integrative boundary objects they are often completed alone by a single practitioner and so do not actively transfer knowledge at all. They also do not fit the concept of an active immutable mobile, transforming and translating knowledge to a centre of calculation, as they are essentially static. However they can become active.

The BPIM described how in the event of a project not performing, perhaps being over budget, as indicated by a much stronger actor-network (the finance system), he would locate the relevant project file, and look for any evidence that the project was not complying with standardized PM procedures. This process creates a rather incongruous situation whereby an individual in a position of formal authority judges whether a seemingly prescriptive PM tool, that is encouraged to be flexible applied, is compliant with a retrospectively imposed ideal. In this ad-hoc audit process the ambiguity between the prescriptive material content of the project file and the locally adapted file, shifts from being a necessary reflexive component of PM knowledge (Cicmil et al. 2006), to a radically arbitrary instrument of control and power, through which the BPIM can invoke narratives of noncompliance and negligence. The ability of the project file to oscillate between a "black-boxed" prescriptive standard 
(technological determinism) and a "boundary objects” of local workarounds (social determinism) is crucial in enabling this power effect.

There are parallels here with Law's (2002) concept of obdurate incoherence. Law (2002) explains how “many inequalities and distributions”, including class, ideology, gender and race, "are fractional effects of noncoherence" (p200). The project file enacts non-coherence between singularity (prescriptive standard) and multiplicity (reflexive tool). In Law’s (2002) parlance it is fractional coherent object: "more than one and less than many" (p194). The interference between these two different modalities affords this object multiplicity (Mol, 2002), even functional blankness (Hetherington, 2000). It empowers the BPIM to register an indefinite number of ambiguities between global and local practice - oscillating from STYLE B to A auditing - and perhaps in the wake disciplining a project team, office or division. Hence the Project File can, on occasion, provide an exceptional conduit through which to exact stress, de-motivation, blame, longer-hours, oppression and alienation over practitioners whose projects fail to perform - exactly the pernicious consequences of project work criticized by Hodgson and Cicmil (2008) and Cicmil et al. (2009a). The agency of the BPIM, and the audit, is constructed through the obdurate incoherence that the project file enacts. The project file does not causally determine the actions of the BPIM or the auditors; rather it affords those actors with a degree of unpredictability, or agency, to act by virtue of its fractional (non)coherence.

The Project File appears to be either singular object (prescriptive standard) or multiple (reflexive tool), yet it is both concurrently. If we do not appreciate its 
fractional coherence then we cannot address its unpredictable power effects that are the result of such oscillations between singularity and multiplicity. The clamour for more adaptable and flexible PM knowledge tools seems to aid this oscillation by enabling a level of reticence towards universal standards increasing the distance from prescriptive content, whilst leaving the material scaffold of those standards remarkably intact.

Such complex power effects are easily forgotten in practice within CivCo. Object non-coherence itself remains invisible: the Project File is often viewed, as as either a singular "black-boxed” object of compliance or a mediator (i.e. "boundary object”) integrating multiple knowledge practices. The interference between aspects of its largely standardizing material content, prescriptive role in the audit, and localized flexibility is further obscured by its relative invisibility as it is forgotten in filing cabinets. Through its incoherent obduracy, this object appears to topologically fold space and time in the organization (Mol and Law, 1994): practitioners forget in the present, associations they form with past material objects which can ambiguously redefine their future practices.

\section{Concluding Comments}

By refusing to take sides in the oscillation between technical and social determinism (and interlinked dualisms of nature/culture, object/subject, human/nonhuman et cetera), ANT can help us understand the socio-material relations through which some of the inequalities, and power relations, within project-based organizations are performed. Viewed through ANT, it becomes evident that more adaptable, 
contextualized and flexible PM knowledge tools are not necessarily an antidote to the pernicious power effects and command and control practices of mainstream PM. Moreover perhaps if flexible knowledge tools fundamentally eviscerated power structures, compliance and control, then they would not be useful to organizations (cf. Morris, 2006). However, this case study reveals that such reflexive tools far from diminishing, or at least counterbalancing, control practices, and social inequalities, can covertly strengthen them. Indeed if, for example, a project fails because a highly prescriptive process is followed it is considerably more difficult to place blame and perhaps extract longer hours from employees than if a prescriptive process is adapted. Law (1994) argues that bureaucracies often support organizational, and social, equalities rather than threaten them, providing a measure of certainty and stability to protect employees against more virtuoso, but destabilizing, and sometimes oppressive, work practices. Similarly, Fleming and Spicer (2003) propose that exaggerated rule-following might sometimes provide a basis of resistance to managerial power and corporate culture, not least because the effects of rulefollowing are often much more unpredictable, and difficult for managers to challenge, than local workarounds to rules.

In this case, the structured, prescriptive and standardized material content of the object combined with its interpretative flexibility and its material obduracy (forgotten in a filing cabinet), offers a potent mix of non-coherence and invisibility through which power effects were distributed to actors such as the BPIM and the audit. Whilst there are clearly benefits to more reflexive PM knowledge tools, the findings suggest that it is not sufficient to extol the benefits of such knowledge practices without fully understanding the nuanced socio-material associations they 
can and do form. Law’s (2002) concept of fractional coherence helped reveal one trajectory of the knowledge/power of objects, which oscillate between technical singularity and interpretative multiplicity. The concepts presented in this study are only a sample of the contribution that ANT-related studies can make of the power effects of PM knowledge tools and their relationship to other knowledge practices, especially auditing. We hope it provides new insights into the relationship between standardized and reflexive knowledge practices, such as PM, and provides conceptual imperatives and methodological tools to respond to those practitioners who continue to ask, "Who reads the project file?"

\section{Acknowledgements}

We would like to thank the three anonymous reviewers for their productive comments on an earlier draft of this paper and the guest editors for their guidance in developing its theoretical contribution.

\section{References}

Akrich, M. and Latour, B. (1992) A Summary of a Convenient Vocabulary for the Semiotics of Human and Nonhuman Assemblies, In: Bijker, W, B. Law, J. Shaping Technology Building Society: Studies in Sociotechnical Change, MIT Press, Cambridge, Mass, 259-264.

Armstrong, P. (2005) What animals mean, in 'Moby-Dick', for example, Textual Practice, 19(1), 93-111.

Bellini E. and Canonico, P. (2008) Knowing communities in project driven organizations: Analysing the strategic impact of socially constructed HRM practices, International Journal of Project Management, 26, 44-50. 
Bresnen, M., Goussevskaia, A. and Swan, J. (2005) Implementing change in construction project organizations: exploring the interplay between structure and agency, Building Research and Information 33(6), 547-560.

Cacciatori, E. (2008) Memory Objects in Project Environments: Storing, Retrieving and Adapting Learning in Project-Based Firms, Research Policy, 37, 1591-1601.

Callon, M. and Latour, B. (1981) Unscrewing the Big Leviathan: how actors macrostructure reality and how sociologists help them to do so. In: Knorr-Cetina, K, D. and Cicourel, A, V. (Eds.) Advances in Social Theory and Methodology: Toward an Integration of Micro- and Macro-Sociologies. Boston, Mass, Routledge and Kegan Paul, 277-303.

Callon, M. (1986) Some Elements of a Sociology of Translation: Domestication of the Scallops and the Fishermen of Saint Brieuc Bay. In: Law, J. (ed) Power, Action and Belief: a new Sociology of Knowledge? Routledge and Kegan Paul, London.

Cicmil, S. (2006) Understanding Project Management Practice Through Interpretative and Critical Research Perspectives, Project Management Journal 37(2), 27-37.

Cicmil, S., Williams T., Thomas J. and Hodgson D (2006) Rethinking Project Management: Researching the actuality of projects, International Journal of Project Management 24(8), 675-686.

Cicmil, S., Hodgson, D., Lindgren, M. and Packendorff, J. (2009a) Project Management Behind the Façade, Ephemera, 9(2), 78-92.

Cicmil, S., Cooke-Davies, T., Crawford, L. and Richardson, K. (2009b) Exploring the Complexity of Projects: Implications of Complexity Theory for Project Management Practice, Project Management Institute, Newtown Square, PA. 
Crawford, L., Morris., P. Thomas, J. and Winter, M (2006) Practitioner development: From trained technicians to reflective practitioners, International Journal of Project Management, 24(8), 722-733.

Crawford, L. and Pollack, J. (2007) How Generic are Project Management Knowledge and Practice, Project Management Journal, 38(1), 87-96.

Czarniawska, B. and Hernes, T. (2005) Actor-Network Theory and Organizing. Copenhagen Business School Press, Malmo.

de Laet, M. and Mol., A. (2000) The Zimbabwe Bush Pump: Mechanics of a Fluid Technology, Social Studies of Science, 30(2), 225-263.

Egan, J. (1998) Rethinking Construction, Construction Task Force Report for Department of Environment, Transport and the Regions, HMSO, London.

Ewenstein, B. and Whyte, J. (2009) Knowledge Practices in Design: The Role of Visual Representations as ‘Epistemic Objects’, Organization Studies, 30(1), 07-30.

Fleming, P. and Spicer, A. (2003) Working at a Cynical Distance: Implications for Power, Subjectivity and Resistance, Organization, 10(1), 157-179.

Foucault, M. (1977) Discipline and Punish: The Birth of the Prison, Pantheon Books, London.

Fournier, V. and Grey, C. (2000) At the Critical Moment: Conditions and Prospects for Critical Management Studies, Human Relations, 53(2), 7-32. 
Georg, S. and Tryggestad, K. (2009) On the emergence of roles in construction: the qualculative role of project management, Construction Management and Economics, 27(10), 969-981.

Green, S, D. (2006) The Management of Projects in the Construction Industry: Context, Discourse and Self-Identity, In: Hodgson, D. and Cicmil, S. (eds.) Making Projects Critical, Palgrave, Basingstoke, 232-251.

Haraway, D, J. (1997) Modest Witness@Second Millenium Female Man@ Meets Oncomouse ${ }^{\mathrm{TM}}:$ Feminism and Technoscience, London, Routledge.

Harty, C. (2005) Innovation in construction: a sociology of technology approach, Building Research and Information, 33(6), 512-22.

Hetherington, K. (2000) Social order and the blank figure, Environment and Planning D: Society and Space, 18(2), 169-184.

Hodgson, D. and Cicmil, S. (eds.) (2006a) Making Projects Critical, Palgrave McMillan, Basingstoke, Hampshire.

Hodgson, D. and Cicmil, S. (2006b) Are Projects Real? The PMBOK and the Legitimation of Project Management Knowledge. In: D. Hodgson and S. Cicmil (eds.) Making Projects Critical, Palgrave McMillan: Basingstoke, Hampshire, 29-50.

Hodgson, D. and Cicmil, S. (2008) The Other Side of Projects: The Case for Critical Project Studies, International Journal of Managing Projects in Business, 1(1), 142152.

Hodgson, D. and Cicmil, S. (2007) The Politics of Standards in Modern Management: Making The Project' a Reality, Journal of Management Studies 44(3), 431-450. 
Jary, D. (2002) Aspects of the 'Audit Society’: Issues Arising from the Colonization of Professional Academic Identities by a 'Portable Management Tool'. In: Dent, M. and Whitehead, S. Managing Professional Identities: Knowledge, Performativity and the 'New' Professional, Routledge, London, 38-60.

Jha, K, N. and Iyer, K, C. (2007) Commitment, Coordination, Competence and the Iron Triangle, International Journal of Project Management 25(5), 527-540.

Koskinen, K. and Makinen, S. (2009) Role of boundary objects in negotiations of project contracts, International Journal of Project Management, 27(1), 31-8.

Kulatunga, U., Amaratunga, D. and Haigh, R. (2009) Critical success factors of construction research and development, Construction Management and Economics, 27(9), 891-900.

Latour, B. (1987) Science in Action: How to Follow Scientists and Engineers Through Society, Harvard University Press, Cambridge, Mass.

Latour, B. (2005) Reassembling the Social: An Introduction to Actor-Network Theory, Oxford University Press: Oxford.

Law, J. (1986) On the Methods of Long Distance Control: Vessels, Navigation, and the Portuguese Route to India. In: Law, J. (ed.) Power, Action and Belief: A New Sociology of Knowledge? Routledge, London, 234-263.

Law, J. (1991) Power, discretion and strategy. In: Law, J. A Sociology of Monsters: Essays on Power, Technology and Domination. London, Routledge, 165-191. 
Law, J. (1994) Organizing Modernity, Blackwell, Oxford.

Law, J. (2002) Aircraft Stories: Decentring the Object in Technoscience, Duke University Press, Durham, NC.

Law, J. (2007) Actor Network Theory and Material Semiotics, version of $25^{\text {th }}$ April 2007, available at http://www.heterogenities.net/publications/Law-

ANTandmaterialsemiotics.pdf , downloaded 27/9/2008.

Law, J. and Singleton, V. (2005) Object Lessons, Organization, 12(3), 331-355.

Lee, N. and Brown., S. (1994) Otherness and the Actor-Network, American Behavioral Scientist 37(6), 772-790.

Linde, A. and Linderoth, H, C, J. (2006) An Actor-Network Theory Perspective on IT Projects. In: Hodgson, D. and Cicmil, S. (eds.) Making Projects Critical, Palgrave McMillan. Basingstoke, Hampshire, 155-170.

Marshall, D. (2006) Understanding power in project settings. In: Hodgson, D. and Cicmil, S. (eds) Making Projects Critical, Palgrave McMillan, Basingstoke, Hampshire, 207-231.

Middleton, D. and Brown, S. D. (2005) Net-working on a Neonatal Intensive Care Unit: The Baby as Virtual Object. In: Czarniawska, B. and Hernes, T. (eds) ActorNetwork Theory and Organizing, Copenhagen Business School Press, Malmo, 307328.

Mol, A. (2002) The Body Multiple: Ontology in Medical Practice, Duke University Press, Durham, NC. 
Mol, A. and. Law. J. (1994) Regions, Networks and Fluids, Social Studies of Science, 24(4), 641-671.

Molloy, E. and Whittington, R. (2006) Reorganization projects and five uncertainties, in Hodgson, D. and Cicmil, S. (eds.) (2006a) Making Projects Critical, Palgrave McMillan, Basingstoke, Hampshire, 171-189.

Morris, P. W. G., Crawford, L., Hodgson, D., Shepherd, M. M. and Thomas, J. (2006) Exploring the role of formal bodies of knowledge in defining a profession The case of project management, International Journal of Project Management 24(8), 710-721.

Morris, P. (2006) Afterword: making the management of projects critical. In: Hodgson, D. and Cicmil, S. (eds.) (2006a) Making Projects Critical, Palgrave McMillan, Basingstoke, Hampshire, 335-347.

Munro, R. (1999) Power and Discretion: Membership Work in the Time of Technology, Organization 6(3), 429-450.

Power, M. (1997) The Audit Society: The Rituals of Verification, Oxford University Press, Oxford.

Smith, C. (2007) Making Sense of Project Realities, Gower, Aldershot, Hampshire.

Stacey, R. D. (2001) Complex responsive processes in organizations: learning and knowledge creation, Routledge, New York.

Star, S. L. and Griesemer, J. R. (1989) Institutional Ecology, 'Translations' and Boundary Objects: Amateurs and Professionals in Berkeley's Museum of Vertebrate Zoology, 1907-39, Social Studies of Science, 19(3), 387-420. 
Star, S. L. (1991) Power, Technologies and the Phenomenology of Conventions: on being Allergic to Onions. In: Law, J. (ed.) A Sociology of Monsters? Essays on Power, Technology and Domination, London, Routledge.

Styhre, A. (2003) Understanding Knowledge Management: Critical and Postmodern Perspectives, Copenhagen Business School, Malmo.

Walker, A. (2007) Project Management in Construction, Blackwell, London.

Weber, M. (1958) The Protestant Ethic and the Spirit of Capitalism, New York, Charles Scribner's Sons.

Weick, K. (1995) Sensemaking in Organizations, Sage: London.

Wenger, E. (1998) Communities of Practice: Learning, Meaning and Identity, University Press: Cambridge.

Whittle, A. and Mueller, F. (2008) Intra-preneurship and enrolment: Building networks of ideas, Organization, 15(3), 445-462.

Whittle, A. and Spicer, A. (2008). Is Actor-Network Theory Critique? Organization, 29(4), 611-629.

Winch, G. (2002) Managing Construction Projects, Blackwell: Oxford.

Yakura, E, K. (2002) Charting Time: Timelines as Temporal Boundary Objects, Academy of Management Journal, 45(5), 956-970. 
Yeung, J. Chan, A. Chan, D. Kwan Li, L. (2007) Development of a partnering performance index (PPI) for construction projects in Hong Kong: a Delphi Study, Construction Management and Economics, 25(12), 1219-1237. 